\title{
Economic Assessment for Cold Sterilization and Clarification of Pineapple Juice and Coconut Water using Microfiltration
}

\author{
A. Laorko ${ }^{1,2,3}$, S. Tongchitpakdee ${ }^{4} \&$ W. Youravong ${ }^{1,3^{*}}$ \\ ${ }^{1}$ Department of Food Technology, Faculty of Agro-Industry Prince of Songkla \\ University, Hat Yai, 90112, Thailand \\ ${ }^{2}$ LPE's Membrane Learning Center, Liquid Purification Engineering International \\ Co., Ltd, Nonthaburi,11140, Thailand \\ ${ }^{3}$ Membrane Science and Technology Research Center, Prince of Songkla University, \\ Hat Yai, 90112, Thailand \\ ${ }^{4}$ Department of Food Science and Technology, Faculty of Agro-Industry, Kasetsart \\ University, Bangkok, 10900, Thailand
}

\begin{abstract}
This study aims to assess the economical feasibility for production of sterilized/clarified pineapple juice and coconut water using cross flow microfiltration (MF). The data for microfiltration plant design is based on the experimental results from our previous studies. The capacity of processing plant for the juice production is assumed to be 20,000 L/day for each juice. The $0.2 \mu \mathrm{m}$ and $0.1 \mu \mathrm{m}$ hollow fiber membranes are used for producing clarified/sterilized pineapple juice and coconut water respectively. The investment cost and the operating cost under various operating conditions are summarized. The operating condition is found to be a major factor influencing capital cost as well as operation cost. The economic assessment is accomplished for production of $5,000 \mathrm{~m}^{3} /$ year, yielding an interest rate of return of 38.3-53.6 \% and payback period of 1.9-2.6 years for pineapple juice while the yielding an interest rate of return of 19.2-23.2\% and payback period of 3.9-4.4 years for coconut water depending on operating conditions.
\end{abstract}

Keywords: Pineapple juice, coconut water, economic assessment, cold sterilization, microfiltration

\subsection{INTRODUCTION}

The conventional process widely used for tropical fruit juice sterilization is thermal process, significantly affecting the quality of fruit juice such as phytochemical property [1-2]. Microfiltration (MF) can be an alternative process for fruit juice preservation. The advantages of microfiltration in relation to the thermal process are the use of mild temperature. The process and techniques developed therefore can be employed for production of non-thermally or cold sterilized fruit juice which potentially maintain the nutritional quality, phytochemical property and sensorial attributes of the products, so call "freshlike products" [2-5]. However, with the exception of non-thermally sterilization, membrane has not been wildly used within fruit juice industry. The main reasons are: (i) high capital and operating cost; (ii) current regulatory standard can be achieved by conventional processes; (iii) difficulties in disposing of chemical waste from cleaning; (iv) limit experience of the use of membranes for these applications [6]. In addition, the performance of membrane process is dependent on 
membrane fouling and concentration polarization limiting the applications. Thus the techniques for improvement membrane process performance by reducing fouling and concentration polarization are always of interest including critical flux, back pulsing, gas sparging [7-10]. Among them gas spraging is a promising method able to significantly enhance the permeate flux of various feed solutions [8-10]. Our previous studies also indicated that the permeate flux during microfiltration of pineapple juice and coconut water were varied, depending on operating conditions such as cross flow velocity (CFV) and gas sparging [4, 5]. It is known that permeate flux and fouling are key parameters in determination of MF-plant design influencing capital cost and operating cost [11]. However, there is no information of economic assessment of microfiltration pineapple juice and coconut water taking into account the operating condition and flux enhancement effects.

Before making a decision on an investment of microfiltration plant, the feasibility of the project has to be studied. Therefore, this study aim to analyze the capital cost and operating cost for production of non-thermally sterilized/clarified pineapple juice and coconut water by microfiltration based on our data found in the previous study $[4,5,10]$. In addition, the influence of MF-operating conditions (i.e. low crossflow velocity $(\mathrm{CFV}=\mathrm{m} / \mathrm{s}$, high cross flow velocity $(\mathrm{CFV}=$ and with gas sparging) on the capital cost, operation cost, interest rate of return and payback period are also studied.

\subsection{EXPERIMENTAL}

\subsection{Microfiltration Plant Design}

A Schematic diagram of the microfiltration process is shown in Figure 1. A multi-stage system with more than one array is used for achieving desire recovery rate. The design of the membrane system is divided into two stages. For the first stage, the system is designed with two or more modules, arranged in parallel. The operating mode is feed and bleeds system. This system allows to maintain the CFV irrespective of other system parameters which can vary with time or feed composition [12]. The retentate of the juice from the first stage is fed continuously to the second stage in which two or more modules have to be connected in series. In order to compensate the permeate and to maintain a uniform feed flow to each

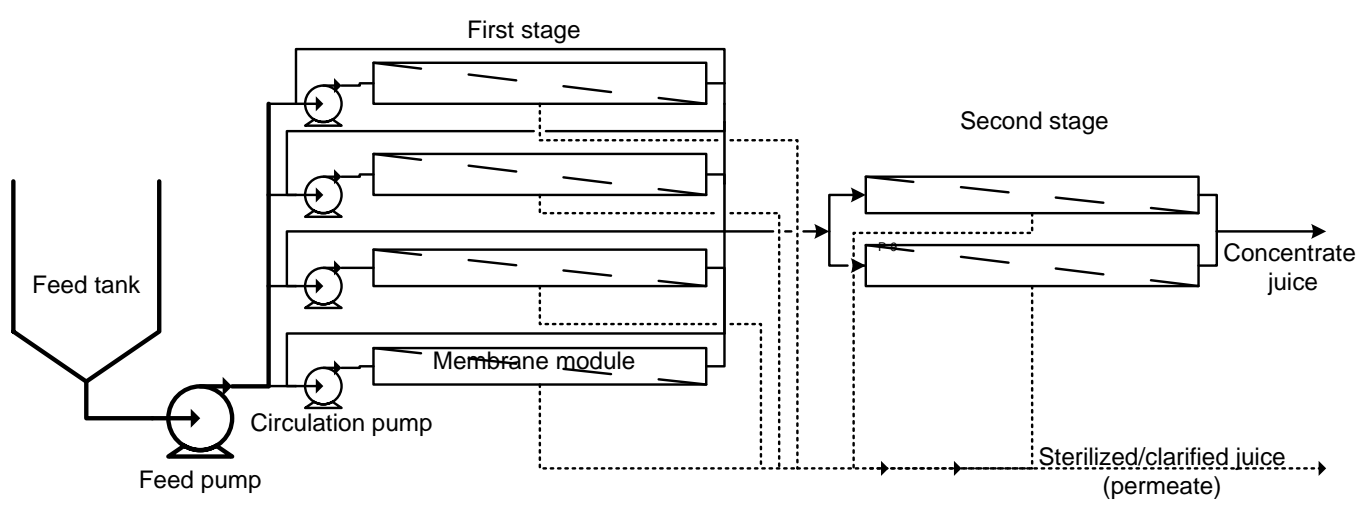

Figure 1 A schematic of a multi-stage microfiltration system 
array, the number of pressure vessels per array decrease in the direction for feed flow [13].

The system consists of membrane unit (hollow fiber membrane), feed tank, pressure transducer, valves, magnetic flow meter, feed and circulation pump and aseptic tank. The system requires 1 circulation pump per 4 membrane modules. The quantity of pumps for each condition is dependent on required membrane area. The membrane specification and characteristics are shown in Table 1.

This study assumes that the membrane system is a new plant in the conventional juice production factory. Therefore, this plant is separated from the existing fruit juice process. The finish product is theoretically sterilized/clarified juice and the estimate cost is in accordant to raw feed juice to the sterilized product in the aseptic tank.

The desired production of sterilized/clarified juice is assumed to be $20,000 \mathrm{~L} /$ day. The production time is $8 \mathrm{~h} /$ day. The recovery of the juice is $90 \%$, so that raw juice of $2800 \mathrm{~L} / \mathrm{h}$ is fed to the MF-system, approximately 2500 $\mathrm{L} / \mathrm{h}$ of permeate (sterilized/clarified juice) and $300 \mathrm{~L} / \mathrm{h}$ of retentate (concentrate juice) are obtained. The concentrate juice can be sterilized using thermal sterilizer and then mixed with the permeate juice to obtain "fresh-like product". However, in this case only permeate is considered as a final product.
Table 1 Specification and characteristics of membranes

\begin{tabular}{|c|c|c|}
\hline Membrane & $\begin{array}{l}\text { Pineapple } \\
\text { juice }\end{array}$ & $\begin{array}{l}\text { Coconut } \\
\text { water } \\
\end{array}$ \\
\hline Pore size & $0.2 \mu \mathrm{m}$ & $0.1 \mu \mathrm{m}$ \\
\hline Model & CFP2E9A & CFP1E9A \\
\hline Length & $63.5 \mathrm{~cm}$ & $63.5 \mathrm{~cm}$ \\
\hline $\begin{array}{l}\text { Fiber } \\
\text { /cartridge }\end{array}$ & 520 fibers & 520 fibers \\
\hline $\begin{array}{l}\text { Fiber lumen } \\
\text { ID }\end{array}$ & $1 \mathrm{~mm}$ & $1 \mathrm{~mm}$ \\
\hline $\begin{array}{l}\text { Membrane } \\
\text { area/cartridge }\end{array}$ & $3.36 \mathrm{~m}^{2}$ & $3.36 \mathrm{~m}^{2}$ \\
\hline $\begin{array}{l}\text { Steam } \\
\text { sterilization }\end{array}$ & Yes & Yes \\
\hline
\end{tabular}

\subsection{Cost Determination}

The main components of the cost of membrane filtration unit for fruit juice processing are capital cost, membrane replacement, power supply, labor, maintenance and chemical agents for cleaning. The total cost is calculated as the sum of this factors expressed as cost per liter of sterilized/clarified juice.

\section{(A) Capital Cost}

The capital cost is considered as the sum of two components: cost of membrane unit and "non membrane" plant. The non-membrane cost includes all mechanical items, electrical items, control equipment and associated civil engineering. Note that no account is taken for land cost.

All membrane costs are estimated from our experience and the information obtained by personnel communication with the membrane suppliers. The membrane life- time is estimated at 5 years. The membrane cost (in Thai Baht, Bht), depending on the membrane area, is $45,000 \mathrm{Bht} / \mathrm{m}^{2}$.

The depreciation period of mechanical engineering costs (pumps, filters, piping, etc.), is 15 years. Similarly, the depreciation period of 
electrochemical investments cost (energy supply, cabling, transformations, control engineering and all electronic components, is 15 years. The working capital cost (for preparation of the installation and support) is estimated at $10 \%$ of the fixed cost.

\section{(B) Operating Cost}

Generally, operation cost is a cost required to run the microfiltration plant. Six main components of operating costs to be considered are:

- Depreciation cost: $10 \%$ of investment of the construction of the installation. The investments are linearly depreciated and interests are neglected.

- Electricity cost: The electricity cost is approximately $2.7 \mathrm{Bht} / \mathrm{kwh}$. In this work, the electricity cost per membrane area operated at high and low CFV (or with gas sparging) are assumed at $5.4 \mathrm{Bht} / \mathrm{m}^{2} / \mathrm{h}$ and $4 \mathrm{Bht} /$ $\mathrm{m}^{2} / \mathrm{h}$, respectively. The electricity cost calculated base on information in Table 2 and 3 are presented in Table 5 and 6.

- Cleaning chemicals: The costs of chemical agent, calculated from the cleaning method in our previous studies are used.

- Maintenance cost is assumed to be $5 \%$ of the total investment cost.

- The quality control cost is assumed to be $2 \%$ of the total investment cost.

- Labor: The number of man-hour per day required to operate the plant is assumed to be proportional to the size of the plant since a significant part of operating time is likely to be associated with membrane cleaning and maintenance. The cost is expected to fall as experience of operating membrane plants increases, since there is much greater potential for automation compared with conventional processes.
Labor cost is taken as 32 Bht per manhour for plant operator.

\section{(C) Capital Investment Decision [14]}

Capital investment decisions are concerned with the production planning, setting goals and priorities, arranging financing and using certain criteria to select long-term assets. The parameters that used for investment decision for this study are payback period time, net present value (NPV) and internal rate of return (IRR), the equation for calculation for each parameter are shown below.

- Payback Period

The payback period is the time required for a firm to recover its original investment. When the cash flows of a project are assumed to be even, the following formula can be used to calculate its payback period;

Payback period $=$ Original

investment/Annual cash flows

If the cash flows are uneven; the payback period is computed by adding the annual cash flows until such time as the original investment is recovered. If a fraction of a year is needed, it is assumed that cash flows occur evenly within each year. One way to use the payback period is to set a maximum payback period for all projects and to reject any project that exceeds this level.

- The net present value method

Discounting models explicitly consider the time value of money and therefore incorporate the concept of discounting cash inflows and outflows. Two discounting models will be considered, net present value (NPV) and internal rate of return (IRR). NPV is the difference between the present value of the cash inflows and outflows 
associated with a project and can be calculated as follows;

$$
\begin{aligned}
\mathrm{NPV} & =\left[\sum \mathrm{CF}_{\mathrm{t}} /(1+\mathrm{i})^{\mathrm{t}}-\mathrm{I}\right] \\
& =\left[\mathrm{CF}_{\mathrm{t}} \mathrm{df}_{\mathrm{t}}\right]-\mathrm{I} \\
& =\mathrm{P}-\mathrm{I}
\end{aligned}
$$

where $\mathrm{I}$ is the present value of the project's cost (usually the initial outlay), $\mathrm{CF}_{\mathrm{t}}$ is the cash inflow to be received in period $t$, with $t=1 \ldots . . n, n$ is the useful life of the project, $i$ is the required rate of return, $t$ is the time period, $\mathrm{P}$ is the present valve of the project's future cash inflows and $\mathrm{df}_{\mathrm{t}}(=$ $\left.1 /(1+i)^{t}\right)$ is the discount factor.

NPV measures the profitability of an investment. If the NPV is positive, it measures the increase in wealth. To use the NPV method, a required rate of return must be defined. The required rate of return is the minimum acceptable rate of return. It is also referred to as the discount rate, the hurdle rate, and the cost of capital.

If the NPV is positive, it signals that (1) the initial investment has been recovered, (2) the required rate of return has been recovered, and (3) a return in excess of (1) and (2) has been received. Thus, if the NPV is greater than zero, the investment is profitable and therefore, is acceptable. If the NPV equals zero, the decision maker will find acceptance or rejection of the investment equal because the investment will earn exactly the required rate of return. Finally, if the NPV is less than zero, the investment should be rejected. In this case, it is earning less than the required rate of return.

- Internal rate of return

Another discounting model is the internal rate of return (IRR) method. The IRR is defined as the interest rate that sets the present value of project's cash inflows equal to the present value of the project's cost. In other words, it is the interest rate that sets the project's
NPV at zero. The following equation can be used to determine a project's IRR.

$$
\begin{aligned}
& \mathrm{I}=\sum \mathrm{CF}_{\mathrm{t}} /(1+\mathrm{I})^{\mathrm{t}} \\
& \text { where } \mathrm{t}=1 \ldots \ldots . \mathrm{n}
\end{aligned}
$$

The right-hand side of equation is the present value of future cash flows, and the left-hand side is the investment. If $\mathrm{I}, \mathrm{CF}_{\mathrm{t}}$ and $\mathrm{t}$ are known, the IRR can be found using trial and error. Once the IRR for a project is computed, it is compared with the firm's required rate of return. If the IRR is greater than the required rate, the project is deemed acceptable. If the IRR is equal to the required rate of return, acceptance or rejection of the investment is equal. If the IRR is less than the required rate of return, the project is rejected.

\subsection{RESULTS AND DISCUSSION}

\subsection{Microfiltration Plant and Operating Condition}

The cost of membranes, membrane replacement and power are calculated, based on the basis of the relationships established from the lab scale trials for flux, CFV, transmembrane pressure (TMP) and pressure drop $(\Delta \mathrm{P})$. It is important to note that since the membrane module length of the industrial scale is about double of the lab scale and the CFV is designed to be same value. This leads to the higher the pressure drop and TMP gradient along the module, potentially affecting the permeate flux and fouling severity. However, in this study, the effect TMP gradient along the membrane module is assumed to be negligible. These results can be used in combination with other factors to obtain a total cost under a range of operating conditions and hence to select optimum conditions. Three operating conditions including low 
CFV $(1.5 \mathrm{~m} / \mathrm{s})$, high CFV $(3.4 \mathrm{~m} / \mathrm{s})$ and additional of gas sparging with gas injection factor $(\varepsilon)$ of 0.35 are used as parameters to calculate the costs of each product. The calculated results then are compared. The details of operating conditions from our previous experiments are given in Table 2 .

As can be seen from Table 2, the highest average permeate flux is achieved when the gas sparging is applied. The lowest permeate flux is achieved when operating at low CFV, thus larger membrane area MF- plant are required (see Table 3 ).

For the pineapple juice, the membrane with pore size of $0.2 \mu \mathrm{m}$ gives the best recovery of phytochemical properties i.e. vitamin C, total phenolic content, and antioxidant capacity [5]. Therefore, this membrane is selected to be the optimal membrane pore size for clarification of pineapple juice. In the case of coconut water, the membrane with pore size of $0.1 \mu \mathrm{m}$ is selected, based on the high permeate flux, low fouling and could completely reserved the juice quality [4]. The optimal operation condition of clarified pineapple juice is $\mathrm{CFV}$ of 1.5 $\mathrm{m} / \mathrm{s}$ and TMP of 0.7 bar with gas injection of 0.35 while optimal operating condition of coconut water is CFV $1.5 \mathrm{~m} / \mathrm{s}$, TMP of 0.65 bar and the $\varepsilon$ of 0.35 .

The capacity of MF processing plant is assumed to be $2800 \mathrm{liter} / \mathrm{h}$ of feed juice. The plant will be operated 250 day/year (2 months off due to low season for raw fruit). The process plant specifications are summarized in Table 3.

\subsection{Cost Estimation}

The building/ room area is a hygienic design. The building cost is estimated at 4,000,000 Bht for each plant. All equipments used are easy to be clean. The construction materials of equipments (fitting, piping, valve, pump etc.) are made of $316 \mathrm{~L}$ stainless steel. The CIP (cleaning in place) system design is taken into consideration with the spray or distribution design.

The quantity of pumps in each system is calculated from the membrane area used. The larger membrane area requires the higher number of circulation pumps. The low $\mathrm{CFV}$ and the gas sparging are used the same type of pump for the circulating the juice, therefore, the high CFV used the larger pump than the low CFV and gas sparging condition. The electrical cost are calculated and shown in Table 5 and 6 .

In calculation of required membrane area, flux values from the our previous studies of pineapple juice and coconut water (shown in Table 3) are used $[4,5,10]$. The required membrane area for MF-plant could be calculated as $A_{m}=Q_{p} / J_{p}$, where $A_{m}$ is the required membrane area, $Q_{p}$ is the permeate flow rate and $\mathrm{Jp}$ is the permeate flux .The membrane price, provided by membrane manufacturing company is $45,000 \mathrm{Bht} / \mathrm{m}^{2}$. The price of membrane for each plant and other costs are shown in Table 5 and 6. It is clearly that when the gas sparging is applied the membrane area is reduced (Table 3 )

The cost of the pressure vessels (MF modules), valve, piping, flow meter, 
Table 2 Selected operation conditions during microfiltration of pineapple juice and coconut water (estimate for the production time of $8 \mathrm{~h}$ )

\begin{tabular}{ccccccccc}
\hline $\begin{array}{c}\text { Fruit } \\
\text { juice }\end{array}$ & $\begin{array}{c}\text { Pore size } \\
(\boldsymbol{\mu \mathbf { m } )}\end{array}$ & \multicolumn{6}{c}{ Without gas sparging } & \multicolumn{6}{c}{ With gas sparging } & \\
\cline { 3 - 9 } & & $\begin{array}{c}\text { Flux } \\
\left(\mathbf{L} / \mathbf{m}^{2} \mathbf{h}\right)\end{array}$ & $\begin{array}{c}\text { TMP } \\
(\mathbf{b a r})\end{array}$ & $\begin{array}{c}\mathbf{C F V} \\
(\mathbf{m} / \mathbf{s})\end{array}$ & $\begin{array}{c}\text { Flux } \\
\left(\mathbf{L} / \mathbf{m}^{2} \mathbf{h}\right)\end{array}$ & $\begin{array}{c}\text { TMP } \\
(\mathbf{b a r})\end{array}$ & $\begin{array}{c}\mathbf{C F V} \\
(\mathbf{m} / \mathbf{s})\end{array}$ & $\begin{array}{c}\text { Gas } \\
\text { injection } \\
\text { factor }\end{array}$ \\
\hline $\begin{array}{c}\text { Pineapple } \\
\text { juice }\end{array}$ & 0.2 & 37 & 0.7 & 3.4 & - & - & - & \\
\hline $\begin{array}{c}\text { Coconut } \\
\text { water }\end{array}$ & 0.2 & 33 & 0.7 & 1.5 & 50 & 0.7 & 1.5 & 0.35 \\
\hline
\end{tabular}

Table 3 Treatment plant specification

\begin{tabular}{|c|c|c|c|c|c|c|}
\hline & \multicolumn{3}{|c|}{$\begin{array}{l}\text { Pineapple juice } \\
\end{array}$} & \multicolumn{3}{|c|}{ Coconut water } \\
\hline & $\begin{array}{l}\text { Low CFV } \\
(1.5 \mathrm{~m} / \mathrm{s})\end{array}$ & $\begin{array}{l}\text { High CFV } \\
(3.4 \mathrm{~m} / \mathrm{s})\end{array}$ & $\begin{array}{l}\text { Gas } \\
\text { sparpging }\end{array}$ & $\begin{array}{l}\text { Low } \\
\text { CFV } \\
(1.5 \text { m/s) }\end{array}$ & $\begin{array}{l}\text { High } \\
\text { CFV } \\
(2.5 \\
\mathrm{m} / \mathrm{s}) \\
\end{array}$ & $\begin{array}{l}\text { Gas } \\
\text { sparging }\end{array}$ \\
\hline Feed & $2800 \mathrm{~L} / \mathrm{h}$ & $2800 \mathrm{~L} / \mathrm{h}$ & $2800 \mathrm{~L} / \mathrm{h}$ & $2800 \mathrm{~L} / \mathrm{h}$ & $2800 \mathrm{~L} / \mathrm{h}$ & $2800 \mathrm{~L} / \mathrm{h}$ \\
\hline permeate & $2500 \mathrm{~L} / \mathrm{h}$ & $2500 \mathrm{~L} / \mathrm{h}$ & $2500 / \mathrm{h}$ & $2500 \mathrm{~L} / \mathrm{h}$ & $2500 \mathrm{~L} / \mathrm{h}$ & $2500 \mathrm{~L} / \mathrm{h}$ \\
\hline Operating time & $8 \mathrm{~h} /$ day & $8 \mathrm{~h} /$ day & $8 \mathrm{~h} /$ day & $8 \mathrm{~h} /$ day & $8 \mathrm{~h} /$ day & $8 \mathrm{~h} /$ day \\
\hline $\begin{array}{l}\text { MF membrane } \\
\text { area }\end{array}$ & $76 \mathrm{~m}^{2}$ & $68 \mathrm{~m}^{2}$ & $46 \mathrm{~m}^{2}$ & $35 \mathrm{~m}^{2}$ & $28 \mathrm{~m}^{2}$ & $23 \mathrm{~m}^{2}$ \\
\hline $\begin{array}{l}\text { Membrane life } \\
\text { time }\end{array}$ & 5 year & 5 year & 5 year & 5 year & 5 year & 5 year \\
\hline $\begin{array}{l}\text { Juice } \\
\text { capacity }\end{array}$ & $5000 \mathrm{~L}$ & $5000 \mathrm{~L}$ & $5000 \mathrm{~L}$ & $5000 \mathrm{~L}$ & $5000 \mathrm{~L}$ & $5000 \mathrm{~L}$ \\
\hline
\end{tabular}

Table 4 Quantity and price of pumps for each condition

\begin{tabular}{cccc}
\hline $\begin{array}{c}\text { Operating } \\
\text { condition }\end{array}$ & $\begin{array}{c}\text { Feed pump } \\
(\text { set } \times \text { price(Bht)) }\end{array}$ & $\begin{array}{l}\text { Circulation pump }( \\
\text { set } \times \text { price(Bht)) }\end{array}$ & $\begin{array}{l}\text { Total } \\
\text { cost((Bht) }\end{array}$ \\
\hline Pineapple juice & & & \\
Low CFV & $1 \times 100,000$ & $6 \times 50,000$ & 400,000 \\
High CFV & $1 \times 100,000$ & $5 \times 80,000$ & 500,000 \\
Gas sparging & $1 \times 100,000$ & $4 \times 50,000$ & 300,000 \\
Coconut water & & & \\
Low CFV & $1 \times 100,000$ & $4 \times 50,000$ & 300,000 \\
High CFV & $1 \times 100,000$ & $3 \times 80,000$ & 340,000 \\
Gas sparging & $1 \times 100,000$ & $2 \times 50,000$ & 200,000 \\
\hline
\end{tabular}

pressure transducer and accessories is $50 \%$ of membrane cost. This cost is estimated according to the report in the literature [15]. The cost of stainless steel feed tank, capacity of $5000 \mathrm{~L}$ is estimated at 200,000 Bhts. The technical electricity cost is assumed to be 500,000 Bht. Working capital cost is $10 \%$ of total fixed capital cost.
The operating costs are membrane replacement, chemical agent, labor, maintenance and depreciation. The membrane is assumed to be replaced every 5 years, therefore the depreciation is $9,000 \mathrm{Bht} / \mathrm{m}^{2} /$ year. The membrane replacement for each condition is shown in Table 5. The chemical agent and cost are $0.5 \mathrm{~N} \mathrm{NaOH}(50 \% \mathrm{NaOH}$, 
33.3 Bht/L) and $50 \mathrm{ppm} \mathrm{NaOHCl} \mathrm{(10 \%}$ $\mathrm{NaOHCl}, 27 \mathrm{Bht} / \mathrm{L})$. The chemical agent is assumed to be $0.02 \%$ of $2500 \mathrm{~L}$ of water used for cleaning. Thus the cost of cleaning of fouled membrane are $50 \mathrm{Bht} / \mathrm{m}^{2}$ (for high CFV and gas sparging) and $45 \mathrm{Bht} / \mathrm{m}^{2}$ (for low CFV). The cleaning cost/ membrane area operated at high CFV and gas sparging are higher than the cost of those operating at low CFV due to the severe fouled membrane. For example, membrane cleaning cost for low CFV condition of pineapple juice is $45($ Baht/day $) \times 250($ day $/$ year $) \times 76($ mem brane area) $=855,000$ Bht. The condition of gas sparging and low CFV consumed lower cleaning cost than the condition of high CFV. It is due to the fact that the gas sparging and low CFV gave the less fouling on the membrane surface during process. The energy associated cost is calculated from the data of the pump and membrane area used. The labor cost, four skill workers for the plant operation and quality control would be 256,000 Bht/year $(4 \mathrm{men} \times 8 \mathrm{~h} \times 32 \mathrm{Bht} / \mathrm{h} \times 250$ day $)$. The maintenance cost is assumed to be $5 \%$ of investment cost while the quality control cost is $2 \%$ of investment cost [11]. The steam energy for sterilization the microfiltration plant is estimated from the amount of steam, required for pre-sterilization of the membrane system at $121{ }^{\circ} \mathrm{C}$ and for heating up of the CIP solution. It estimated cost is $800,000 \mathrm{Bht} /$ year. The cost of nitrogen gas consumption estimated, based on our previous study is 500,000 Bht/year.

The raw material of pineapple juice will be purchased from the pineapple juice plant and the estimated price is 16.5 Bht/L (personal communication with Thai pineapple juice factory). The average price of coconut water is about $5 \mathrm{Baht} /$ fruit, thus the price of raw coconut water is estimated at $15 \mathrm{Bht} / \mathrm{L}$. The costs of sterilized/clarified pineapple juice and coconut water are shown in Table 5 and 6 . The expected price of sterilized/clarified pineapple juice is $18.5 \mathrm{Bht} / \mathrm{L}$ and the expected price of coconut water is $17.5 \mathrm{Bht} / \mathrm{L}$. The estimated sterilized/clarified pineapple juice price is assumed, based on the present pineapple juice price (personal communicate with the pineapple juice exporter). The revenues per year of sterilized/clarified pineapple juice and coconut water for each condition are also shown in Table 5 and Table 6, respectively.

The estimation cost from Table 5 and 6 reveal that the main cost of the capital cost is membrane and membrane system. The capital cost of pineapple juice plant is higher than the cost of coconut water plant due to the lower of permeate flux, thus larger membrane area are required. The results also reveal that the use of gas sparging for flux enhancement could reduces the cost of membrane and membrane replacement and other related cost. However, the cost due to gas consumption needs to be added in the production cost. The production cost of clarified juice/L is shown in Table 7 . The costs of clarified pineapple juice and coconut water calculated from the operating cost shown in Table 5 and 6 are divided by the total clarified juice produced in 1 year $\left(5000 \mathrm{~m}^{3}\right)$.

Table 8 shows the NPV, IRR and payback time of the project for sterilized/clarified pineapple juice and coconut water, operating with various conditions. The economic assessment reveals that the project for cold sterilization/clarification of pineapple juice and coconut water is economically feasible. The payback time for clarified pineapple juice plant with the assisted gas sparging is less than those without assisted gas sparging. It is also evident that the value of IRR and NPV are relatively high. 


\subsection{CONCLUSION}

The microfiltration plants are designed based on three different operating conditions has influence on both fix capital cost and production cost. The assisted gas sparging technique is remarkable benefit for microfiltration pineapple juice plant but less benefit for microfiltration- coconut water plant. The major investment costs of the microfiltration- plant are building cost, followed by membrane cost. The raw juice cost is about $85 \%$ of production cost. The payback period for the pineapple juice plant and coconut water are 1.9-2.6 year and 3.9-.4.4 years respectively, depending on operating conditions. The assisted gas sparging technique in sterilized/clarified pineapple juice production could reduce the payback period at 1.9 years while the assisted gas sparging technique does not reduce payback period in sterilized/clarified coconut water production. From economic point of view and quality aspects therefore microfiltration is an alternative process for cold sterilization/clarification of pineapple juice and coconut water.

\section{ACKNOWLEDGEMENT}

The authors gratefully acknowledge the Faculty of Agro-Industry and Graduate School, Prince of Songkla University and the National Center for Genetic Engineering and Biotechnology (BIOTEC) of Thailand for their financial support (Project code BT-B01-FG-18-5003).

Table 5 Cost for sterilized and clarified pineapple juice processing

\begin{tabular}{lccc}
\hline Cost (Bht.) & \multicolumn{2}{c}{ Operating condition } \\
& Low & High & Gas sparging \\
& CFV & CFV & \\
\hline Fixed capital costs & & & \\
Building & $4,000,000$ & $4,000,000$ & $4,000,000$ \\
MF membrane & $4,040,540$ & $3,420,000$ & $2,070,000$ \\
MF modules, valve, & $1,710,000$ & $1,520,270$ & $1,035,000$ \\
piping and accessories & & & \\
Pump & 400,000 & 500,000 & 300,000 \\
Tank & 200,000 & 200,000 & 200,000 \\
Electro technical cost & 500,000 & 500,000 & 500,000 \\
Working capital 10\% & $1,023,000$ & 976,081 & 810,500 \\
of fixed capital cost & & & \\
Capital investment & $11,253,000$ & $10,738,892$ & $8,815,500$ \\
Expense per year & & & \\
Electricity cost & 855,000 & 912,162 & 529,000 \\
Cleaning & 852,000 & 850,000 & 522,675 \\
Quality control & 225,060 & 214,737 & 178,310 \\
Membrane replacemen & 684,000 & 608,108 & 414,000 \\
Maintenance & 560,650 & 536,844 & 445,775 \\
Operating labour & 256,000 & 256,000 & 256,000 \\
Depreciation & $1,125,300$ & $1,073,689$ & 885,300 \\
Steam energy (lump s & 800,000 & 800,000 & 800,000 \\
Nitrogen gas & - & - & 500,000 \\
Feed juice & $82,500,000$ & $82,500,000$ & $82,500,000$ \\
Revenue (Bht/year) & $92,500,000$ & $92,500,000$ & $92,500,000$ \\
2500 L/h of clarified juice & & & \\
\hline
\end{tabular}




\section{REFERENCES}

[1] Elez-martinase, P, and O, MartinBelloso. 2007. Effect of high intensity pulsed electric field processing conditions on vitamin $\mathrm{C}$ and antioxidant capacity of orange juice and gazpacho, a cold vegetable soup. Food Chem. 102(1): 201-209.

[2] Girard, B, and L. R. Fukumoto. 2000. Membrane processing of fruit juices and beverage: A review. Crit. Rev. J. Food Sci. 40(2): 91-157.

[3] Carneiro, L., S. Santos, D. Iralla, G. Santos, M. Flavia, V. Matta, and C. M. Correa. 2002. Cold sterilization and clarification of pineapple juice by tangential microfiltration. Desalination. 148: 93-98.

[4] Laorko, L., Z. Y. Li, W. Youravong, S. Tongjitpakdee, and S. Chantachum. 2007. Cold sterilization of coconut water using membrane filtration: Effect of membrane property and operating condition. J. Appl. Membr. Sci. Technol. 6: 9-17.

[5] Laorko, A., Z. Y. Li, S. Tongchitpakdee, S. Chantachum, and W. Youravong. 2010. Effect of membrane property and operating conditions on phytochemical properties and permeate flux during clarification of pineapple juice. J Food Eng. 100: 514-521.

[6] Owen, g., M. Bandi, J. A. Howell, and S. J. Churchouse. 1995. Economic assessment of membrane process for water and waste water treatment. J. Membr. Sci. 102: 77-91.

[7] Field, R. W., D. Wu, J. A. Howell, and B. B Gupta. 1995. Critical flux concept for microfiltration fouling. J. Membr. Sci. 100: 259-272.
[8] Cui, Z. F., S. Change, and A. G. Fane. 2003. The use of gas bubbling to enhance membrane processes. J. Membr. Sci. 221: 135.

[9] Li, Z. Y., A. H-Kittikhun, and W. Youravong. 2008. Separation of protease from yellow fin tuna spleen extract by ultrafiltration: effect of hydrodynamics and gas sparging on flux enhancement and selectivity. J. Membr. Sci. 311: 104-111.

[10] Laorko, A., Z. Y. Li, S. Tongjitpakdee, and W. Youravong. 2011. Effect of gas sparging on flux enhancement and phytochemical properties of clarified pineapple juice by microfiltration. Sep. Purif. Technol. 80: 445-451.

[11] Cheryan, M. 1998. Ultrafiltration and Microfiltration Hand Book. $2^{\text {nd }}$ ed. Lancaster: Technommic Publishing Co.

[12] Mannapperuma, J. D. 1997. Design and performance evaluation of membrane system, In Hand book of Food Engineering Practice. Edited by K. Valentas, E. Rotstein and P. R. Singh: New York: CRC Press.

[13] Filmtec. Membrane, System Design: multistage system. Available:

http://www.dow.com/liquidseps/1 it/techman.htm, 25 June 2015.

[14] Hansen, D. R, and M. M. Mowen. 2007. Managerial accounting. $8^{\text {th }}$ ed. Singapore: Cengage Learning Asia.

[15] Mohammad, A. W., N. A Ali, and N. Hilal. 2004. Optimized nanofiltration membranes: relevance to economic assessment and process performance. Desalination. 165: 243-250. 
Table 6 Cost for sterilized and clarified coconut water processing

\begin{tabular}{lccc}
\hline Cost (Bht.) & & Condition & \\
& Low CFV & High CFV & Gas sparging \\
\hline Fixed capital costs & $4,000,000$ & $4,000,000$ & $4,000,000$ \\
Building & $1,575,000$ & $1,260,000$ & $1,032,786$ \\
MF membrane & 787500 & 630,000 & 516,393 \\
MF modules, valve, & & & \\
piping and accessories & 280,000 & 230,000 & 180,000 \\
Pump & 200,000 & 200,000 & 200,000 \\
Tank & 500,000 & 500,000 & 500,000 \\
Electro technical cost & 734,250 & 682,000 & 642,918 \\
Working capital 10\% of & & & \\
fixed capital cost & $12,250,432$ & $10,637,000$ & $8,376,500$ \\
Capital investment & & & \\
Expense per year & 350,000 & 378,000 & 309,836 \\
$\quad$ Electricity cost & 393,750 & 350,000 & 287,500 \\
Cleaning & 161,535 & 150,040 & 141,441 \\
Quality control & 315,000 & 252,000 & 206,557 \\
Membrane replacement & 612,522 & 531,850 & 418,825 \\
Maintenance & 256,000 & 256,000 & 256,000 \\
$\quad$ Operating labour & 807,675 & 750,200 & 707,209 \\
$\quad$ Depreciation & 800,000 & 800,000 & 800,000 \\
$\quad$ Steam energy (lump sum) & - & - & 500,000 \\
Nitrogen gas & $75,000,000$ & $75,000,000$ & $75,000,000$ \\
Feed juice & $87,500,000$ & $87,500,000$ & $87,500,000$ \\
Revenue (Bht/year) & & & \\
2500 L/h of clarified juice & & & \\
\hline
\end{tabular}

Table7 Product cost of sterilized/clarified pineapple juice and coconut water (Bht/liter of product)

\begin{tabular}{lcccccc}
\hline Cost (Bht/L) & \multicolumn{3}{c}{ Pineapple juice } & \multicolumn{3}{c}{ Coconut water } \\
& $\begin{array}{c}\text { Low } \\
\text { CVF }\end{array}$ & $\begin{array}{c}\text { High } \\
\text { CVF }\end{array}$ & gas & Low & $\begin{array}{c}\text { High } \\
\text { CVF }\end{array}$ & $\begin{array}{c}\text { Gas } \\
\text { sparging }\end{array}$ \\
\hline Raw juice & 16.5 & 16.5 & 16.5 & 15 & 15 & 15 \\
Electricity & 0.15 & 0.18 & 0.12 & 0.06 & 0.08 & 0.06 \\
Cleaning & 0.17 & 0.17 & 0.11 & 0.08 & 0.07 & 0.06 \\
Quality control & 0.04 & 0.04 & 0.04 & 0.03 & 0.03 & 0.03 \\
$\quad$ Membrane & 0.14 & 0.12 & 0.08 & 0.06 & 0.05 & 0.04 \\
replacement & & & & & & \\
Maintenance & 0.11 & 0.11 & 0.09 & 0.12 & 0.11 & 0.08 \\
Operating labour & 0.05 & 0.05 & 0.05 & 0.05 & 0.05 & 0.05 \\
Depreciation & 0.22 & 0.21 & 0.18 & 0.16 & 0.15 & 0.14 \\
Steam energy & 0.16 & 0.16 & 0.16 & 0.16 & 0.16 & 0.16 \\
$\quad$ Gas & - & - & 0.10 & - & - & 0.10 \\
Total cost & 17.54 & 17.54 & 17.43 & 15.73 & 15.70 & 15.72 \\
\hline
\end{tabular}


Table 8 Cash flow analysis of pineapple juice and coconut water processing plant

\begin{tabular}{lcccccc}
\hline Cost (Bht/L) & \multicolumn{3}{c}{ Pineapple juice } & \multicolumn{3}{c}{ Coconut water } \\
& $\begin{array}{c}\text { Low } \\
\text { CVF }\end{array}$ & $\begin{array}{c}\text { High } \\
\text { CVF }\end{array}$ & gas & Low & $\begin{array}{c}\text { High } \\
\text { CVF }\end{array}$ & $\begin{array}{c}\text { Gas } \\
\text { Sparging }\end{array}$ \\
\hline Raw juice & 16.5 & 16.5 & 16.5 & 15 & 15 & 15 \\
Electricity & 0.15 & 0.18 & 0.12 & 0.06 & 0.08 & 0.06 \\
Cleaning & 0.17 & 0.17 & 0.11 & 0.08 & 0.07 & 0.06 \\
Quality control & 0.04 & 0.04 & 0.04 & 0.03 & 0.03 & 0.03 \\
$\begin{array}{l}\text { Membrane } \\
\text { replacement }\end{array}$ & 0.14 & 0.12 & 0.08 & 0.06 & 0.05 & 0.04 \\
$\quad$ Maintenance & 0.11 & 0.11 & 0.09 & 0.12 & 0.11 & 0.08 \\
Operating labour & 0.05 & 0.05 & 0.05 & 0.05 & 0.05 & 0.05 \\
Depreciation & 0.22 & 0.21 & 0.18 & 0.16 & 0.15 & 0.14 \\
Steam energy & 0.16 & 0.16 & 0.16 & 0.16 & 0.16 & 0.16 \\
$\quad$ Gas & - & - & 0.10 & - & - & 0.10 \\
Total cost & 17.54 & 17.54 & 17.43 & 15.73 & 15.70 & 15.72 \\
\hline
\end{tabular}

